\title{
Mechanisms for Effectiveness: A Look Into the Child Friendly School System in Junior High School
}

\author{
Marvin O. Ranario ${ }^{1}$, Lyoid C. Hunahunan ${ }^{2}$ \\ ${ }^{1}$ Secondary School Faculty, ${ }^{2}$ College Instructor \\ ${ }^{1}$ Barobo National High School, Barobo, Surigao Del Sur, Philippines \\ ${ }^{2}$ Surigao Del Sur State University, Tagbina Campus, Tagbina, Surigao Del Sur, Philippines
}

\begin{abstract}
Effectiveness is one of the dimensions of child friendly school system. Effectiveness in education means to ensure the fulfilment of each learners' right to quality education. This emphasizes the dynamics of the teaching and learning process. On that note, this study investigated the level of implementation on the effectiveness of Child Friendly School System in the junior high school level of Barobo National High School, Barobo, Surigao del Sur, Philippines. Respondents consist of 3 school administrators, 47 teachers, 50 Grade 10 students, and 50 parents of Grade 10 students. The study used the descriptive method where the respondents were asked about their evaluation of the program through a survey questionnaire. It was found out in the study that the Child Friendly School System was implemented to a very satisfactory level in terms of effectiveness. This goes to show that the said junior high school was able to deliver well in terms of how teachers and learners interact in the classroom and the usage of instructional materials to achieve positive learning outcomes. There are however areas which need to be improved, and in order to do so, this entails collective efforts of both the internal and external stakeholders of the school.
\end{abstract}

Key Words: child-friendly school, child friendly school system, effectiveness, junior high school, mechanisms

\section{INTRODUCTION}

Implementation, when combined with outcome evaluations, can help in the identification of effective programs and practices. Through program evaluation, the individual can determine whether activities are realized as intended and identify their strengths and weaknesses. This hereby provides insights on how they should be designed and implemented in order to produce a positive result (Duerden \& Witt, 2012). Hence, to assess the success of child friendly school system (CFSS) which is one of the programs implemented in public schools in the Philippines, this study endeavored to evaluate the program in terms of its effectiveness.

Effectiveness is pointed out as one of the dimensions of child friendly school system. Effectiveness in education according to UNESCO (1994) is to ensure the fulfilment of each learners' right to quality education. This means creating a learning environment that promotes and demonstrates a broad definition of quality.

In -addition to UNESCO's statement, effective education includes a quality learning environments, containing guidelines and practices which forbid aggravation, disgrace, violence, physical reprimand, and substance abuse; amenities with adequate classrooms, clean water supplies, sanitation facilities, and services that promote safety and physical and psychosocial health; quality learners who are healthy, ready to learn, and sustained by their family and community; excellence in teaching-learning processes and content with child-centered and life skills-based methods and skill applications to decrease inequalities and stimulate learning; relevant instruction and ample materials for literacy, numeracy, and the vital information and skills for life; quality results, with clear learning outcomes; (awareness, approaches, and skills) and appropriate methods to evaluate them at classroom and national levels. 
Several studies have been conducted relative to CFSS implementation. Enueme (2011), in her evaluation of the program disclosed that the system has positive impact to both the children, teachers, and the school community as a whole. In another study of Orkodashvili's (2010), it was found out that experience is now showing that a framework of rights-based, child-friendly schools can be a powerful tool for both helping to fulfill the rights of children and providing them an education of good quality. Moreover, Chidi (2013) also pointed out that quality assurance should be demonstrated through capacity building and monitoring by the government and UNICEF. Hence, there should be constant in-service training of teachers on child friendly pedagogies.

In the Philippines, it was in 1999 that the childfriendly school system was introduced and was piloted in 131 elementary schools, with the goal of improving education quality by transforming schools into healthy, tolerant, inclusive and protective learning environments. The Department of Education expanded fifty three (53) public secondary schools in 2006 and 2007, respectively. However, though this system has been implemented in the country for long years already, studies conducted about it have been scarce. Hence, this study primarily aimed to address such demand to evaluate the system in the Philippine context. Particularly, this study is focused on the CFSS implementation of Barobo National High School in Surigao del Sur which has been one of the child-friendly schools in the country since 2011. More so, while the aforesaid studies gauged the system in foreign countries in a broader dimension, the present study is more specific as it puts emphasis only on its effectiveness.

Fundamentally, the present study school could lend insights to administrators and other stakeholders regarding the status quo of the program implementation. This study will also give a concrete idea to the policy-makers and program implementers as to the real context of child-friendly school system as implemented; and thus revisit the policies pertaining to it. Furthermore, these data could be utilized to fortify the child-friendly school system not only in the institutions where this study is conducted but in all implementing academes through intervention activities if necessitated.

\section{Research Methodology}

To determine the level of effectiveness on the implementation of child friendly school system of Barobo Nationl High School, the researchers used the descriptive method by noting significant statistics that was derived through qualitative description. It collected data at a particular point in time with intention of describing the nature or identifying the standards. The study adopted this strategy because it is best used when collecting information about people's perceptions and opinions. This method enabled the researchers to bring out the level of implementation of CFSS in terms of effectiveness.

The locale of the study was in Barobo National High School, Barobo, Surigao del Sur, Philippines. It is one of the implementing schools of child-friendly school system in the Philippines. A total of 150 participants were taken as sample for the study. To determine this number, the researchers utilized the universal sampling for the 3 school administrators and 47 teachers. For the 50 grade 10 students, the researchers used the stratified random sampling, and for 50 parents from grade 10, the researchers employed the convenience sampling method.

The researchers made use of questionnaire as a survey instrument adapted from the original questionnaire formulated by UNESCO. The researchers made some modifications by focusing on one dimension only which is effectiveness. In this dimension, three key performance area were evaluated namely: mechanisms for a constructive policy and management environment for learning; mechanisms for good, quality-centered teaching and learning processes and outcomes; and mechanisms for enhanced teacher capacity, morale and motivation. The drafted questionnaire underwent validation from experts before it was used. Experts suggested to translate the items in vernacular for better understanding of the respondents. A five-point Likert scale was used to quantify the perceptions of the respondents.

After all data were gathered, the Statistical Package for Social Science (SPSS) Version 16 was utilized by the researcher to ensure reliable interpretations. To find out the level of implementation in terms of effectiveness, weighted mean was used where the scores were interpreted as follows: 
International Journal of Trend in Scientific Research and Development (IJTSRD) ISSN: 2456-6470

Table1. Interpretation on the level of implementation on the Effectiveness of Child Friendly School System

\begin{tabular}{|c|c|l|}
\hline Scale & Level & \multicolumn{1}{c|}{ Interpretation } \\
\hline $4.50-5.00$ & Excellent & $\begin{array}{l}\text { if the item in the questionnaire is always implemented by } \\
\text { the school having a very accurate description }\end{array}$ \\
\hline $3.50-4.49$ & Very satisfactory & $\begin{array}{l}\text { if the item in the questionnaire is often implemented by the } \\
\text { school having accurate description }\end{array}$ \\
\hline $2.50-3.49$ & Satisfactory & $\begin{array}{l}\text { if the item in the questionnaire is sometimes implemented } \\
\text { by the school having partly accurate description } \\
\text { if the item in the questionnaire is seldom implemented by } \\
\text { the school having a poor description }\end{array}$ \\
\hline $1.50-2.49$ & Fair & $\begin{array}{l}\text { if the item in the questionnaire is never implemented by the } \\
\text { school having a very poor description }\end{array}$ \\
\hline $1.00-1.49$ & Poor &
\end{tabular}

\section{Results and Discussion}

The level of implementation of child-friendly school implementation of child-friendly school system in system as perceived by the respondents is shown in terms of effectiveness as very satisfactory with the Table 2. The three groups of respondents rated the mean rating of 4.30 .

Table2. Summary on the Level of Implementation on the Effectiveness of Child Friendly School System as Perceived by the Respondents

\begin{tabular}{|c|c|c|c|c|c|c|c|}
\hline KEY PERFORMANCE AREA & $\begin{array}{r}\text { Sch } \\
\text { Offic }\end{array}$ & & Stud & ents & Par & ents & Total \\
\hline $\begin{array}{l}\text { Kpa } 1 . \text { A constructive policy and nternat } \\
\text { management environment for learning. }\end{array}$ & 4.42 & $\mathrm{VS}$ & 4.24 & VS & 4.18 & VS & $4.28(\mathrm{VS})$ \\
\hline $\begin{array}{l}\text { Kpa 2. Good, quality-centered teaching and } \\
\text { learning processes and outcomes. }\end{array}$ & 4.32 & VS & 4.15 & VS & 4.52 & $\mathrm{E}$ & $4.33(\mathrm{VS})$ \\
\hline $\begin{array}{l}\text { Kpa 3. Enhanced teacher capacity, morale, } \\
\text { and motivation }\end{array}$ & 4.46 & $\mathrm{VS}$ & - & 9 & 4.18 & VS & $4.32(\mathrm{VS})$ \\
\hline Overall & 4.40 & VS & 4.20 & VS & 4.30 & VS & $4.30 \quad \mathrm{VS})$ \\
\hline
\end{tabular}

School officials' perception. Effectiveness was divided into a constructive policy and management environment for learning (KPA1) which was rated by the school officials with 4.42 (very satisfactory). As presented in Table 3, item regarding the clear understanding of school mission and vision statement among internal and external stakeholders (item 1) was given a highest rating of 4.94 (excellent). This can be observed during the school and classroom-based orientation conducted by the administrators and teachers every opening of classes in June. Meanwhile, item about the exemption of families with financial constrain from school fees was rated by the respondents (item 11) as implemented satisfactorily with mean score of 3.12. This result justified that the school collected school fees on a legal matter across all learners. Categorizing financial capability in every learner was not evident. School collected fees through school governing council.

Table3. Level of Implementation of CFSS in Terms of Effectiveness as perceived by the School Officials in KPA 1

\section{KPA 1. A CONSTRUCTIVE SCHOOL POLICY AND}

MANA GEMIENT ENVIRONMIENT FOR LEARNING

1. The school has a clear mission and/or vision statement that is prominently displayed and adequately explained to all school personnel, students, parents, and community members.

2. The school has and enforces policies on inclusive, child-friendly education, including a policy against discrimination as well as the exclusion of students on the basis of pregnancy and motherhood

\begin{tabular}{|c|c|c|}
\hline Mean & $\begin{array}{c}\text { Descriptive } \\
\text { Level }\end{array}$ & Rank \\
\hline 4.94 & Excellent & 1 \\
\hline 4.66 & Excellent & 11 \\
\hline
\end{tabular}


International Journal of Trend in Scientific Research and Development (IJTSRD) ISSN: 2456-6470

3. The school is aware of and is changing policies and practices - such as costs and daily schedules - that prevent children with diverse backgrounds and abilities from receiving a quality education.

4. The school has, monitors, and enforces policies against gender discrimination in enrolment and teaching.

5. The school has policies against gambling, violence (especially bullying), pornography, the use of tobacco, alcohol, and other addictive substances on school grounds by teachers, staff, and students.

6. The school has, monitors, and enforces policies against corporal punishment.

7. The school has, monitors, and enforces a code of behavior for teachers regarding proper and improper interpersonal teacher relations as well as teacher-student relations.

8. The school has, monitors, and enforces policies against the sexual harassment and abuse of students and teachers.

9. The school has, monitors, and enforces policies on proper sanitation and hygiene.

10. The school has, monitors, and enforces policies on the delivery of simple school health and nutrition packages including counselling.

11. Poor families are exempted from school fees (direct and indirect).

12. Monitoring mechanisms exist to identify students prone of dropping out.

13. The school principal provides strong direction and leadership guided by a written supervisory plan.

14. Teachers, students, and parents participate in school management, as well as school development planning.

15. There are adequate numbers of desks, chairs, and classrooms that fit the needs and abilities of all students.

16. School buildings and facilities are clean, safe, and regularly maintained.

17. An adequate waste disposal system is available and well maintained.

18. All students have inclusive, gender-friendly textbooks and associated learning materials.

19. Each classroom has adequate teaching aides, materials, technologies, and equipment for all subjects.

20. The school has adequate extra-curricular activities for children and associated equipment.

21. The school has adequate support staff (number, capabilities) to facilitate operations.

Mean

\begin{tabular}{|c|c|c|}
\hline 4.26 & $\begin{array}{c}\text { Very } \\
\text { Satisfactory }\end{array}$ & 15 \\
\hline 4.36 & $\begin{array}{c}\text { Very } \\
\text { Satisfactory }\end{array}$ & 14 \\
\hline 4.9 & Excellent & 4 \\
\hline 3.94 & $\begin{array}{c}\text { Very } \\
\text { Satisfactory }\end{array}$ & 17 \\
\hline 3.96 & $\begin{array}{c}\text { Very } \\
\text { Satisfactory }\end{array}$ & 16 \\
\hline 3.62 & $\begin{array}{c}\text { Very } \\
\text { Satisfactory }\end{array}$ & 20 \\
\hline 4.92 & Excellent & 2 \\
\hline 4.82 & Excellent & 6.5 \\
\hline 3.12 & Satisfactory & 21 \\
\hline 4.9 & Excellent & 4 \\
\hline 4.82 & Excellent & 6.5 \\
\hline 4.68 & Excellent & 10 \\
\hline 4.9 & Excellent & 4 \\
\hline 4.76 & Excellent & 9 \\
\hline 4.52 & Excellent & 13 \\
\hline 3.72 & $\begin{array}{c}\text { Very } \\
\text { Satisfactory }\end{array}$ & 19 \\
\hline 3.74 & $\begin{array}{c}\text { Very } \\
\text { Satisfactory }\end{array}$ & 18 \\
\hline 4.56 & Excellent & 11 \\
\hline 4.8 & Excellent & 8 \\
\hline 4.42 & $\begin{array}{c}\text { Very } \\
\text { Satisfactory }\end{array}$ & \\
\hline
\end{tabular}

On the other hand, the mechanism for quality-centered teaching and learning processes and outcomes (KPA2) was rated by the school officials as very satisfactorily implemented with mean score of 4.32. Items regarding educational materials and learning resources which promote active learning and gender sensitivity (item 2) and the prevention of negative communication among teachers and students (item 6) garnered the same lowest mean scores of 3.74 with descriptive level of very satisfactory (see Table 4). This is affirmed by Florian (2009) that negative communication between teachers and students would mark a hostile psychological upshot to the learners. Based on his recommendation school administrators, teachers, students and parents should submit 
International Journal of Trend in Scientific Research and Development (IJTSRD) ISSN: 2456-6470

themselves to a seminar about behavior and personal management and even anger management or a recollection activities. Meanwhile, item about students' participation according to their interest in any related school related activities (item 8) garnered the highest rating of 4.96 (excellent). This can be justified through different awards received by the school from the division level of competition up to the national level.

Table4. Level of Implementation of CFSS in Terms of Effectiveness as perceived by the School Officials in KPA 2

\section{KPA 2. GOOD QUALITY, CHILD-CENTRED TEACHING AND LEARNING PROCESSES AND OUTCOMIES \\ 1. The curriculum and classroom work address each child's learning needs} as well as those of the community in a meaningful, practical way.

2. Educational materials, textbooks, writing tools, and learning resources are gender sensitive and encourage active learning in a language that children can understand.

3. The principal and teachers are familiar with child-centered and childfriendly principles.

4. There is an adequate student-teacher ratio and distribution by subject.

5. All teachers are trained and actively monitoring children's rights within the school and community.

6. Negative communication is avoided. Children are not scolded.

7. All students are treated equally without regard to their sex, background, or ability.

8. All students participate in school activities according to their interests

9. Each classroom has a 'learning corner' with supplementary learning materials and displays of student work.

10. The goals of lessons and activities are clear to learners at each step in the learning process.

11. Parents receive information from the school about their children's attendance, participation, and achievement.

Mean

\begin{tabular}{|c|c|c|}
\hline Mean & $\begin{array}{c}\text { Descriptive } \\
\text { Level }\end{array}$ & Rank \\
\hline 3.84 & $\begin{array}{c}\text { Very } \\
\text { Satisfactory }\end{array}$ & 8 \\
\hline 3.74 & $\begin{array}{c}\text { Very } \\
\text { Satisfactory }\end{array}$ & 10.5 \\
\hline 4.02 & $\begin{array}{c}\text { Very } \\
\text { Satisfactory }\end{array}$ & 7 \\
\hline 4.76 & Excellent & 4 \\
\hline 4.2 & $\begin{array}{c}\text { Very } \\
\text { Satisfactory }\end{array}$ & 6 \\
\hline 3.74 & $\begin{array}{c}\text { Very } \\
\text { Satisfactory }\end{array}$ & 10.5 \\
\hline 4.78 & Excellent & 3 \\
\hline 4.96 & Excellent & 1 \\
\hline 4.7 & Excellent & 5 \\
\hline 3.76 & $\begin{array}{c}\text { Very } \\
\text { Satisfactory }\end{array}$ & 9 \\
\hline 4.9 & Excellent & 2 \\
\hline 4.32 & $\begin{array}{c}\text { Very } \\
\text { Satisfactory }\end{array}$ & \\
\hline
\end{tabular}

Further, the enhanced teacher capacity, morale, and motivation (KPA3) of effectiveness was rated by the school officials as very satisfactorily implemented with mean score of 4.46. Item about the conduct of annual medical check-ups among teachers and staff (item 10) were rated by the respondents as excellent with the mean score of 5.00 (see Table 5). This rating can be attributed on the annual medical check-up initiated by the school for the teachers and staff. Medical check-up was done as part of the brigada eskwela program of the school. The said health services were conducted by the personnel who are alumni of the school whose profession is health related while the medicines and other health materials were shouldered by both local and provincial government.

Table5. Level of Implementation of CFSS in Terms of Effectiveness as perceived by the School Officials in KPA 3

\section{KPA 3. ENHANCED TEACHER CAPACITY,} MORALE, AND MOTIVATION

1. The school assesses teachers' needs and wants, and develops personnel and school plans for fulfilling these.

2. The school takes positive steps to increase teacher recognition, such as facilitating promotions and achievement sharing.

3. Transparency is ensured in recruitment, appointment, and transfer (merit basis; gender balance).

\begin{tabular}{|c|c|c|}
\hline Mean & $\begin{array}{c}\text { Descriptive } \\
\text { Level }\end{array}$ & Rank \\
\hline 3.96 & $\begin{array}{c}\text { Very } \\
\text { Satisfactory }\end{array}$ & 10.5 \\
\hline 4.66 & Excellent & 8 \\
\hline 4.06 & $\begin{array}{c}\text { Very } \\
\text { Satisfactory }\end{array}$ & 9 \\
\hline
\end{tabular}


International Journal of Trend in Scientific Research and Development (IJTSRD) ISSN: 2456-6470

\begin{tabular}{|c|c|c|c|}
\hline $\begin{array}{l}\text { 4. Concrete actions are taken to increase safe environments for } \\
\text { teachers, especially women (e.g., reduce sexual harassment). }\end{array}$ & 3.8 & $\begin{array}{l}\text { Very } \\
\text { Satisfactory }\end{array}$ & 12 \\
\hline $\begin{array}{l}\text { 5. The principal regularly monitors teachers' performance and provides } \\
\text { needed support in a constructive, non-threatening manner. }\end{array}$ & 4.84 & Excellent & 4 \\
\hline $\begin{array}{l}\text { 6. Teachers support their co-teachers by sharing teaching techniques } \\
\text { and experiences. }\end{array}$ & 4.94 & Excellent & 2 \\
\hline $\begin{array}{l}\text { 7. Teachers have regular opportunities for professional capacity } \\
\text { building (e.g., teacher networks, workshops, study tours, regular } \\
\text { sharing meetings) and means for professional advancement (e.g., } \\
\text { special projects, research, publications). }\end{array}$ & 4.8 & Excellent & 6 \\
\hline $\begin{array}{l}\text { 8. Teachers are given opportunities to innovate (e.g., development of } \\
\text { classroom resources, new teaching/learning methods [esp. for } \\
\text { dealing with diverse classrooms], work with communities to } \\
\text { increase resources and address important issues such as } \\
\text { stigmatization and gender inequality). }\end{array}$ & 4.68 & Excellent & 7 \\
\hline 9. Teachers have their own lounge and/or work area. & 4.72 & Excellent & 5 \\
\hline 10. Teachers and other staff are given annual medical check-ups. & 5 & Excellent & 1 \\
\hline $\begin{array}{l}\text { 11. Tools/toolkits and other resources are provided to teachers on time } \\
\text { management, lesson planning, curriculum development, classroom } \\
\text { management, disciplinary options, children's participation in } \\
\text { teaching and learning in the classroom, etc. }\end{array}$ & & $\begin{array}{l}\text { Very } \\
\text { Satisfactory }\end{array}$ & 13 \\
\hline $\begin{array}{l}\text { 12. Libraries, textbooks, and teaching aids are readily available and used } \\
\text { by teachers to facilitate teaching } \\
\text { and their children's learning. }\end{array}$ & 3.96 & $\begin{array}{l}\text { Very } \\
\text { Satisfactory }\end{array}$ & 10.5 \\
\hline $\begin{array}{l}\text { 13. "Self-assessment tools" are available for teachers to monitor their } \\
\text { own progress and ways to continue improving upon it. }\end{array}$ & 4.88 & Excellent & 3 \\
\hline Mean 30 Research and & 4.46 & $\begin{array}{l}\text { Very } \\
\text { Satisfactory }\end{array}$ & \\
\hline
\end{tabular}

Students' perception. The students' evaluation on a constructive policy and management environment for learning (KPA1) of effectiveness was 4.24 as implemented very satisfactorily. Table 6, shows that the adequacy of classroom teaching aids, materials, technologies, and equipment for all subjects (item 13) was given the lowest mean score 3.64 (very satisfactory). The result implies that the school has teaching aids, materials, technology and equipment but the ratio towards the number of user was not enough. A shortage of materials and facilities were manifested. With this kind of scenario, school officials, teachers, and parents would look into their partners for some assistance to address these problems. On the other hand, item pertaining on the safety of school playground (item 8) were rated by students as excellent with mean score of 4.84. It implies that the school followed and provided safety precautions to the learners. This can be observed through the signage posted in the different corners of the school and hazard map posted in the classrooms. It even conducted hazard and precaution and first-aid seminar to students. This was asserted by Toson (2013) that it is the responsibility of the school to educate its learner about safety and precaution. Students spent most of their time in school. Despite the firm implementation of the school about the policy on safety, still learners cannot be exempted on accidents either minor or major.

Table6. Level of Implementation of CFSS in Terms of Effectiveness as perceived by Grade 10 Students in KPA 1

KPA 1. A CONSTRUCTIVE SCHOOL POLICY AND MANAGEMIENT ENVIRONMIENT FOR LEARNING

1. The school has a clear mission and/or vision statement that is prominently displayed and adequately explained to all school personnel, students, parents, and community members.
Mean Descriptive Level Rank
Very Satisfactory 
International Journal of Trend in Scientific Research and Development (IJTSRD) ISSN: 2456-6470

2. The school has policies against gambling, violence (especially bullying), pornography, the use of tobacco, alcohol, and other addictive substances on school grounds for students.

3. The school has, monitors, and enforces policies against corporal punishment.

4. The school has monitors, and enforces policies against the sexual harassment and abuse of students

5. The school has monitors, and enforces policies on proper sanitation and hygiene

6. The school has monitors, and enforces policies on the delivery of simple school health and nutrition packages including counselling.

7. There are adequate numbers of desks, chairs, and classrooms that fit the needs and abilities of all students.

8. The school grounds allow students to play safely.

9. School buildings and facilities are clean, safe, and regularly maintained.

10. Classrooms are orderly and have adequate lighting and ventilations.

11. Adequate numbers of clean and separate latrines are available to, and used by girls and boys

12. All students have inclusive, gender-friendly textbooks and associated learning materials.

13. Each classroom has adequate teaching aids, materials, technologies, and equipment for all subjects.

Mean

\begin{tabular}{|c|c|c|}
\hline 4.74 & Excellent & 2 \\
\hline 3.78 & $\begin{array}{c}\text { Very } \\
\text { Satisfactory }\end{array}$ & 11.5 \\
\hline 4.78 & $\begin{array}{c}\text { Very } \\
\text { Satisfactory }\end{array}$ & 11.5 \\
\hline 3.24 & $\begin{array}{c}\text { Very } \\
\text { Satisfactory }\end{array}$ & 8 \\
\hline 4.62 & $\begin{array}{c}\text { Very } \\
\text { Satisfactory }\end{array}$ & 9 \\
\hline 4.84 & Excellent & 3.5 \\
\hline 4.62 & Excellent & 1 \\
\hline 4.48 & $\begin{array}{c}\text { Very } \\
\text { Satisfactory }\end{array}$ & 3.5 \\
\hline 4.54 & $\begin{array}{c}\text { Excellent } \\
\text { Eery }\end{array}$ & 5 \\
\hline 3.84 & $\begin{array}{c}\text { Very } \\
\text { Satisfactory }\end{array}$ & 10 \\
\hline 3.64 & $\begin{array}{c}\text { Very } \\
\text { Satisfactory }\end{array}$ & 13 \\
\hline 4.24 & $\begin{array}{c}\text { Very } \\
\text { Satisfactory }\end{array}$ & 5 \\
\hline 3.98
\end{tabular}

Moreover, the students evaluated the quality-centered teaching and learning processes and outcomes (KPA2) of effectiveness as very satisfactory with mean score of 4.15. Item regarding on the situation of teachers scolding their students (item 7) rated the least mean score of 3.48 with descriptive level of satisfactory (see Table 7). This result was aligned to the perception of the respondents on the negative communication between teachers and students. Stanovich and Jordan (2002) stated that giving negative feedback towards learners in a coarse process created psychological disturbance to the learners. It resulted to a decline of the academic performance of the learners. Meanwhile item about encouraging students to work together as a group and to solve problems on a flexible manner (item 10) was rated as excellent with mean score of 4.62. This can be observed on the sustainability and intensification of the implementation of mentoring and buddy system program of the school. On the other hand, students did not evaluate the enhanced teacher capacity, morale, and motivation (KPA3) of effectiveness because this dimension focused only on teacher's motivation and morale development which they know less about.

Table7. Level of Implementation of CFSS in Terms of Effectiveness as perceived by Grade 10 Students in KPA 2

\section{KPA 2. GOOD QUALITY, CHILD-CENTRED TEACHING AND LEARNING PROCESSES AND OUTCOMES \\ 1. The curriculum and classroom work address each child's learning needs as well as those of the community in a meaningful, practical way.}

2. Educational materials, textbooks, writing tools, and learning resources are gender sensitive

3. Teachers encourage and promote cooperative, 'hands-on' learning ('learning by doing').

\begin{tabular}{|c|c|c|}
\hline Mean & $\begin{array}{c}\text { Descriptive } \\
\text { Level }\end{array}$ & Rank \\
\hline 3.74 & $\begin{array}{c}\text { Very } \\
\text { Satisfactory }\end{array}$ & 13 \\
\hline 3.68 & $\begin{array}{c}\text { Very } \\
\text { Satisfactory }\end{array}$ & 14 \\
\hline 4.24 & $\begin{array}{c}\text { Very } \\
\text { Satisfactory }\end{array}$ & 7 \\
\hline
\end{tabular}


International Journal of Trend in Scientific Research and Development (IJTSRD) ISSN: 2456-6470

\begin{tabular}{|l|c|c|c|}
\hline 4. Teachers encourage students to think and decide for themselves & 4.12 & $\begin{array}{c}\text { Very } \\
\text { Satisfactory }\end{array}$ & 9 \\
\hline 5. All teachers encourage participation in the classroom & 4.02 & $\begin{array}{c}\text { Very } \\
\text { Satisfactory }\end{array}$ & 10 \\
\hline $\begin{array}{l}\text { 6. Teachers provide guidance and advice concerning each child's } \\
\text { continued education }\end{array}$ & 4.22 & $\begin{array}{c}\text { Very } \\
\text { Satisfactory }\end{array}$ & 8 \\
\hline 7. Children are not scolded. & 3.48 & Satisfactory & 15 \\
\hline $\begin{array}{l}\text { 8. All students are treated equally without regard to their sex, } \\
\text { background, or ability. }\end{array}$ & 3.76 & Very & 12 \\
\hline $\begin{array}{l}\text { 9. All students masters their ability and skills of writing, reading, } \\
\text { speaking and listening, arithmetic, and the necessary skills that they } \\
\text { can use for life }\end{array}$ & 4 & Satisfactory & 11 \\
\hline $\begin{array}{l}\text { 10. All students are encouraged to work together in flexible groups to solve } \\
\text { problems and achieve what they aim to do }\end{array}$ & 4.62 & Excellent & 1 \\
\hline $\begin{array}{l}\text { 11. All students are encouraged to express their views and feelings through } \\
\text { the arts (music, drawing, drama) or other mechanisms, particularly } \\
\text { concerning activities and life in the school. }\end{array}$ & 4.5 & Excellent & 4.5 \\
\hline 12. All students participate in school activities according to their interests & 4.5 & Excellent & 4.5 \\
\hline $\begin{array}{l}\text { 13. Classroom learning is dynamic and active } \\
\text { 14. Each classroom has a 'learning corner' with supplementary learning } \\
\text { materials and displays of student work. }\end{array}$ & 4.34 & Sery & 6 \\
\hline $\begin{array}{l}\text { 15. The goals of lessons and activities are clear to learners at each step in } \\
\text { the learning process. }\end{array}$ & 4.52 & Excellent & 2.5 \\
\hline $\begin{array}{l}\text { Mean } \\
\text { Ex }\end{array}$ & 4.15 & Satisfactory & Verlent \\
\hline
\end{tabular}

Parents Perception. Parents evaluated the constructive policy and management environment for learning (KPA1) of effectiveness as very satisfactorily implemented with mean score of 4.18. Based on the data presented on Table 8, it was observed that item about the exemption of poor families from school fees (item 7) was rated as satisfactory with a mean score of 3.02. This result is aligned to the response of the school officials and students. This might be overlooked by the school administrators where the consistency of the response entails that school collected school fees without identifying the students' financial background.

Table8. Level of Implementation of CFSS in Terms of Effectiveness as perceived by the parents in KPA 1

\section{KPA 1. A CONSTRUCTIVE SCHOOL POLICY AND MANA GEMIENT ENVIRONMIENT FOR LEARNING}

1. The school has a clear mission and/or vision statement that is prominently displayed and adequately explained to all school personnel, students, parents, and community members.

2. The school is aware of and is changing policies and practices such as costs and daily schedules - that prevent children with diverse backgrounds and abilities from receiving a quality education.

3. The school has, monitors, and enforces policies against gender discrimination in enrolment and teaching.

4. The school has policies against gambling, violence (especially bullying), pornography, the use of tobacco, alcohol, and other addictive substances on school grounds by teachers, staff, and students.

\begin{tabular}{|c|c|c|}
\hline Total & $\begin{array}{c}\text { Level of } \\
\text { Implementation }\end{array}$ & Rank \\
\hline 4.8 & Excellent & 1 \\
\hline 3.28 & $\begin{array}{c}\text { Very } \\
\text { Satisfactory }\end{array}$ & 5 \\
\hline 4.74 & $\begin{array}{c}\text { Very } \\
\text { Satisfactory }\end{array}$ & 6 \\
\hline
\end{tabular}


International Journal of Trend in Scientific Research and Development (IJTSRD) ISSN: 2456-6470

\begin{tabular}{|l|c|c|c|}
\hline $\begin{array}{l}\text { 5. } \\
\text { The school has monitors, and enforces policies against corporal } \\
\text { punishment. }\end{array}$ & 4.38 & $\begin{array}{c}\text { Very } \\
\text { Satisfactory }\end{array}$ & 4 \\
\hline $\begin{array}{l}\text { 6. } \\
\text { The school has, monitors, and enforces policies on the delivery } \\
\text { of simple school health and nutrition packages including } \\
\text { counselling. }\end{array}$ & 4.64 & $\begin{array}{c}\text { Very } \\
\text { Satisfactory }\end{array}$ & 3 \\
\hline 7. Poor families are exempted from school fees (direct and indirect). & 3.02 & Satisfactory & 8 \\
\hline $\begin{array}{l}\text { 8. Parents have opportunities and appropriate channels to } \\
\text { participate in school management }\end{array}$ & 3.5 & $\begin{array}{c}\text { Very } \\
\text { Satisfactory }\end{array}$ & 7 \\
\hline Mean & 4.18 & $\begin{array}{c}\text { Very } \\
\text { Satisfactory }\end{array}$ & \\
\hline
\end{tabular}

Also, parents rated the quality-centered teaching and learning processes and outcomes (KPA2) of effectiveness as excellently implemented with mean score of 4.52. Table 9 indicates that items regarding the dissemination of information to the parents as to their children's attendance, participation and achievement (item 3) was 4.9 and item about the livelihood training in the community as provided (item 2) was 4.8. Both items were perceived by the respondents as excellently implemented. This can be justified on the quarterly meeting conducted by the school aside from the general PTA assembly and the home visitation program for students vulnerable of dropping out. Also, the school initiates community extensions through the Technical and Vocational Education department with their program Train which provides training on different skills among external stakeholders of the school.

Table9. Level of Implementation of CFSS in Terms of Effectiveness as perceived by the parents in KPA 2

\begin{tabular}{|c|c|c|c|}
\hline $\begin{array}{l}\text { KPA 2. GOOD QUALITY, CHILD-CENTRED TEACHING } \\
\text { AND LEARNING PROCESSES AND OUTCOMIES }\end{array}$ & Parents & $\begin{array}{c}\text { Level of } \\
\text { Implementation }\end{array}$ & Rank \\
\hline $\begin{array}{l}\text { 1. The curriculum and classroom work address each child's } \\
\text { learning needs as well as those of the community in a and } \\
\text { meaningful, practical way. }\end{array}$ & 3.86 & $\begin{array}{l}\text { Very } \\
\text { Satisfactory }\end{array}$ & 3 \\
\hline 2. The school provides livelihood training in the community & 4.8 & Excellent & 2 \\
\hline $\begin{array}{l}\text { 3. Parents receive information from the school about their } \\
\text { children's attendance, participation, and achievement. }\end{array}$ & 4.9 & Excellent & 1 \\
\hline Mean & & Excelle & \\
\hline
\end{tabular}

In addition, the parents rated the enhanced teacher capacity, morale, and motivation (KPA3) of effectiveness as very satisfactorily implemented with mean score of 4.18. Table 10 shows that the highest of 4.32 (very satisfactory) was on item about the increase of resources through the collaborative effort among external stakeholders and the school (item 1). It was followed by item on the mobilization of community to support teachers on their classroom needs (item 3) with mean score of 4.22 (very satisfactory). Item about the collaboration among the school and the external stakeholders to address gender inequality (item 2) although last on the rank, but was rated by the respondents as very satisfactorily implemented with a mean score 4.02. This means that the school services or program like linking with external stakeholders to generate resources address important issues like gender equality, and mobilize community to support teachers were evident and observed by the parents.

Table10.Level of Implementation of CFSS in Terms of Effectiveness as perceived by the parents in KPA3

\begin{tabular}{|l|c|c|c|}
\hline KPA 3. ENHANCED TEACHER CAPACITY, MORALE, AND & Parents & $\begin{array}{c}\text { Level of } \\
\text { Implementation }\end{array}$ & Rank \\
\hline $\begin{array}{l}\text { 1. The school works with the external stakeholders to increase } \\
\text { resources }\end{array}$ & 4.32 & $\begin{array}{c}\text { Very } \\
\text { Satisfactory }\end{array}$ & 1 \\
\hline
\end{tabular}


International Journal of Trend in Scientific Research and Development (IJTSRD) ISSN: 2456-6470

\begin{tabular}{|l|c|c|c|}
\hline $\begin{array}{l}\text { 2. The school works with the external stakeholders to address } \\
\text { important issues such as gender inequality. }\end{array}$ & 4.02 & $\begin{array}{c}\text { Very } \\
\text { Satisfactory }\end{array}$ & 3 \\
\hline $\begin{array}{l}\text { 3. The community is mobilized to support teachers and their } \\
\text { teaching (e.g., 'Teachers Day,' assistant teachers, providing } \\
\text { classroom resources, facility expansion). }\end{array}$ & 4.22 & $\begin{array}{c}\text { Very } \\
\text { Satisfactory }\end{array}$ & 2 \\
\hline Mean & 4.18 & $\begin{array}{c}\text { Very } \\
\text { Satisfactory }\end{array}$ \\
\hline
\end{tabular}

Generally, the respondents evaluated the implementation of Child Friendly School System in terms of effectiveness as very satisfactory with mean score of 4.30. The school official rated this dimension as very satisfactory with mean score 4.40 followed by the parents who perceived the program as very satisfactorily implemented with mean score of 4.30 . Lastly, the students gave a very satisfactory rating of 4.20. This manifests that in terms of effectiveness, the school was able to deliver well on this CFSS dimension. For the construction of policy and management environment, it was evident from the responses of the respondents that a collaborative policy formulation was a common practice of the school. Both internal and external stakeholders created a shared governance through the creation of School Governing Council. On the other hand, other school services particularly on the child-centered and learning process like intensifying school program that would address the gap in every learning materials to be child friendly, teachers resourcefulness in aligning their instructional materials and teaching pedagogy were rated low by the students who were the end receiver and user of the said services. Also, the facilities particularly the some toilets for boys and girls were not separated.

Meanwhile, item on teacher's motivation and morale like the annual medical check-up rendered by the school was an evidence that the school administrators really cared for the welfare of the teacher particularly on the health aspects, and item on the regular monitoring of teacher's performance and providing an assessment tool to evaluate themselves in terms of personal, career and professional growth were rated by the respondents as excellently implemented. Another indication that the school provide the teachers with their needs to make their teaching fruitful and meaningful. It showed that teacher were motivated intrinsically and extrinsically.

UNESCO (1994) affirmed that a motivated teacher created a passionate teacher, and a passionate teacher produces a child-friendly teacher. In return, teacher would not be child friendly if the school is not a teacher-friendly. In addition, Byrk (2010) stated that if the school is teacher friendly, motivational drive will be developed among teachers and they will spend more time, giving motherly care in teaching. There will be low teacher absenteeism and there will be an increased use of innovative, child-centered learning methods that show definite results in improving learning achievement.

\section{Conclusion}

Drawn from the findings above, it can be deduced that the child friendly school system as implemented in the junior high school level of Barobo National High School was implemented on a very satisfactory level in terms of effectiveness. This goes to show that the said junior high school was able to deliver well in terms of the dynamics in the teaching and learning process - how teachers and learners interact in the classroom and the usage of instructional materials to achieve positive learning outcomes. There are however areas which need to be improved, and in order to do so, this entails collective efforts of both the internal and external stakeholders of the school.

\section{References}

1. Bryk, A.S. (2010). Organizing Schools for Improvement. Phi Delta Kappan, 91(7).

2. Chidi, J.L. (2013). Early childhood classroom teachers' perceptions of successful inclusion: a multiple case study. Retrieved from http://eric. ed.gov./ED433936

3. Duerden, M.T. \& Witt, P.T. (2012). Assessing Program Implementation: What It Is, Why It's Important, and How to Do it. Retrieved on March 13, 2016. http://www.joe.org/joe/2012february/a4.php

4. Enueme, Chika Peace, Ph.D., (2003) The Impact Of Child-Friendly School Initiative Federal College of Education (Technical) PMB 1044, Delta State, Nigeria 
International Journal of Trend in Scientific Research and Development (IJTSRD) ISSN: 2456-6470

5. Florian, L. (2009). Preparing Teachers To Work In 'Schools For All.' Teaching and Teacher Education, 25, 533-534.

6. Orkodashvili, M. (2010). Quality education through Child-Friendly Schools: resource allocation for the protection of children's rights. Access on March 23, 2016 at scholar.google.be

7. Stanovich, P. J., \& Jordan, A. (2002). Preparing General Educators to Teach In Inclusive
Classrooms: Some Food For Thought. The Teacher Educator, 37, 173-185.

8. Toson, A.L. (2013). Examining school capacity for inclusion using a multi-dimensional framework: a case study. Retrieved on February 9, 2016 from http://scholarcommons.usf.edu/etd

9. UNESCO (1994). The Salamanca Statement and Framework on Special Needs Education. Paris: UNESCO

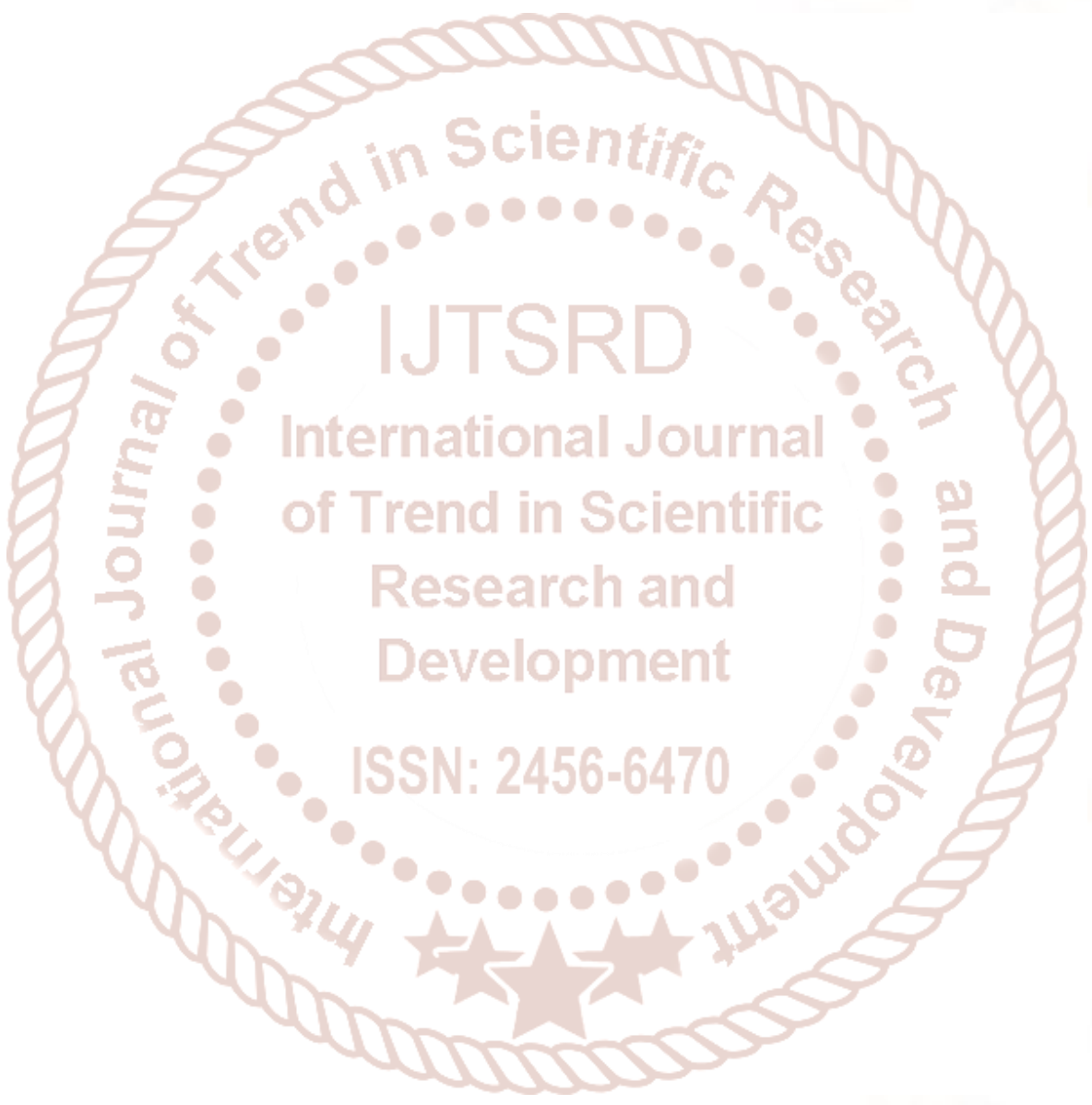

